\title{
Aux Ecoutes
}

\section{CALL FOR PAPERS}

\section{FRENCH PHILOSOPHERS IN AMERICA:}

Descartes, Montesquieu, Rousseau, Sartre, and?

Their Place in Teaching, Their Impact on Research

\section{CONFERENCE}

Sponsored by the Société Américaine de Philosophie de Langue Française

in conjunction with the APA meeting

WHEN: 27-30 December 1990

WHERE: Boston

Abstracts to: Peter Caws

Department of Philosophy

The George Washington University

Washington, D.C. 20052

by October 1,1990 